\section{Dalea purpurea 'Stephanie'}

\author{
Dale T. Lindgren ${ }^{1}$ and Daniel M. Schaaf ${ }^{2}$ \\ University of Nebraska, West Central Research and Extension Center, North \\ Platte, NE 69101
}

Additional index words. purple prairie-clover, Petalostemon purpurea

Dalea L. (prairie-clover) is a large genus of the western hemisphere consisting of herbaceous and shrubby plants (Great Plains Flora Association, 1986). Barneby (1977) lists over 160 species that range from the Canadian prairies into South America. The forage value of daleas for livestock is well known (Stubbendieck et al., 1989). Ornamentally, daleas are showy plants, desirable for their foliage as well as for their delicate flowers (Locklear and Vickerman, 1997; Starr, 1988). Their value as a legume can also contribute to sustainable landscapes.

Dalea purpurea Vent., formerly designated as Petalostemon purpureus (Vent.) Rydb., and sometimes listed as Dalea purpureum, is found growing from the Canadian prairie provinces to Texas and from the eastern edge of the Rocky Mountains throughout most of the prairie region of the U.S. Midwest (Great Plains Flora Association, 1986; Stubbendieck et al., 1989). It is a perennial herb with a thick woody taproot. Dalea purpurea is often associated with mid- and tall-growing plants, including big bluestem (Andropogon gerardii Vitman), little bluestem (Schizachyrium scoparium Michx. Nash), prairie sandreed (Calamovilfa longifolia Hook. Scrihn), side-oats grama (Bouteloua curtipendula Michx. Torr), rough gayfeather (Liatris aspera Michx.), black sampson (Echinacea angustifolia DC.), dotted gayfeather (Liatris punctata Hook.), and leadplant (Amorpha canescens Pursh) (Salac et al., 1978). Plants are spreading to erect and grow to a height of 0.15 to $0.9 \mathrm{~m}$. Stems are few to many with glandular dots and ribs. Leaves are alternate, short-stalked, 1.3 to $5 \mathrm{~cm}$ long, 1.3 to $2.5 \mathrm{~cm}$ wide, and odd-pinnately compound, with 3 to 7 linear leaflets. Inflorescences are usually compact, densely flowered, cylindrical spikes produced at the ends of stems.

Individual flowers are small; the calyx is five-lobed and densely hairy; the petals are reddish-purple, about $6 \mathrm{~mm}$ long; and there are five protruding yellow stamens. Fruits are small (2 to $2.5 \mathrm{~mm}$ long), smooth, and egg-shaped, each containing a single 1.5- to 2-mm-long, yellowish-green to brownish seed covered with small dots. Blooming period is May to August.

Received for publication 21 Mar. 2002. Accepted for publication 5 Aug. 2002. Paper No. 13617, Journa Series, Nebraska Agricultural Research Division. Research was conducted under Projects No. NEB 43-047 and NEB 43-066. We acknowledge financial support for the development of this cultivar from the Perennial Plant Association and the Nebraska Statewide Arboretum.

${ }^{1}$ Professor; to whom reprint requests should be addressed.E-mail address: dlindgren1@unl.edu

${ }^{2}$ Agriculture Research Technician.
The plant flowers from the base toward the apex (Barneby, 1977; Farrar, 1990; Stubbendieck et al., 1989). One seed-propagated line, 'Kaneb', has been released (Salac et al.,1978).

\section{Origin}

Two populations of $D$. purpurea were evaluated for variation in height, stem color, foliage color, flowering time, stem count, and lodging (Lindgren, 1992). Source 1 (467 plants) was the cultivar Kaneb (Stock Seed Farm, Murdock, Nebr.) and source 2 (278 plants) came from the Nebraska Federated Garden Clubs' wildflower distribution program (Nebraska source). In 1988, seed was collected from $5 \%$ of the plants of each population that displayed the most desirable traits. The seed collected from each of the two populations was combined and planted in 1989. In 1990, all plants that had lodged, had light green or yellow foliage color, had fewer than 20 stems per plant, or had a height of over $50 \mathrm{~cm}$ were rogued from the field and discarded. Only the most desirable plants remained. These plants were left in the field for further evaluation with the intent to allow pollination to occur between the remaining selections. Seed was collected from these plants in 1991 and germinated, and seedlings were field transplanted in 1992. In 1993, these
Fig. 1. Dalea purpurea 'Stephanie'. seedlings were evaluated for the ornamental traits of height, foliage color, and lodging. Seed from four individual plants with desirable horticultural traits, including high stem counts, low lodging, shorter height, and attractive green foliage, was collected and planted in 1994, keeping each source as a separate population. Each population was evaluated for ornamental traits. Population \#4, with the most uniform, compact plants and multiple stems, was selected for further studies.

Seeds from plants in this population were selected and used to establish field plantings for final evaluation and seed production. All plants were grown in field plots at the Univ. of Nebraska West Central Research and Extension Center, North Platte. The field soil at the evaluation site was a Cozad silt loam (fine-silty, mixed, mesic Fluventic Haplustoll) soil, pH 7.6. Plants were irrigated at transplanting time in the field and then only as needed during the growing season.

In 1997 and 1998, seed emergence studies on this selection were conducted where seed was given either a cold, moist treatment for 6 weeks or no treatment ( 0 weeks). Seeds were sown $7 \mathrm{~mm}$ deep in a peat-lite mix (Redi-Earth, Scotts Co., Marysville, Ohio) contained in 50 $\times 35 \times 7 \mathrm{~cm}$ metal flats. Soil was moistened and placed in an unheated facility where temperatures were kept at $0 \pm 2{ }^{\circ} \mathrm{C}$. At the end of 6 weeks, an additional set of trays was prepared in the same manner. Both treatments were placed in the greenhouse, where temperatures were maintained at a minimum of $24{ }^{\circ} \mathrm{C}$ day $/ 12{ }^{\circ} \mathrm{C}$ night under natural photoperiods and irradiance levels. Treatments were replicated four times with 50 seeds per replicate with each replicate in a different flat each year. The number of seedlings that emerged was recorded every other day for 6 weeks.

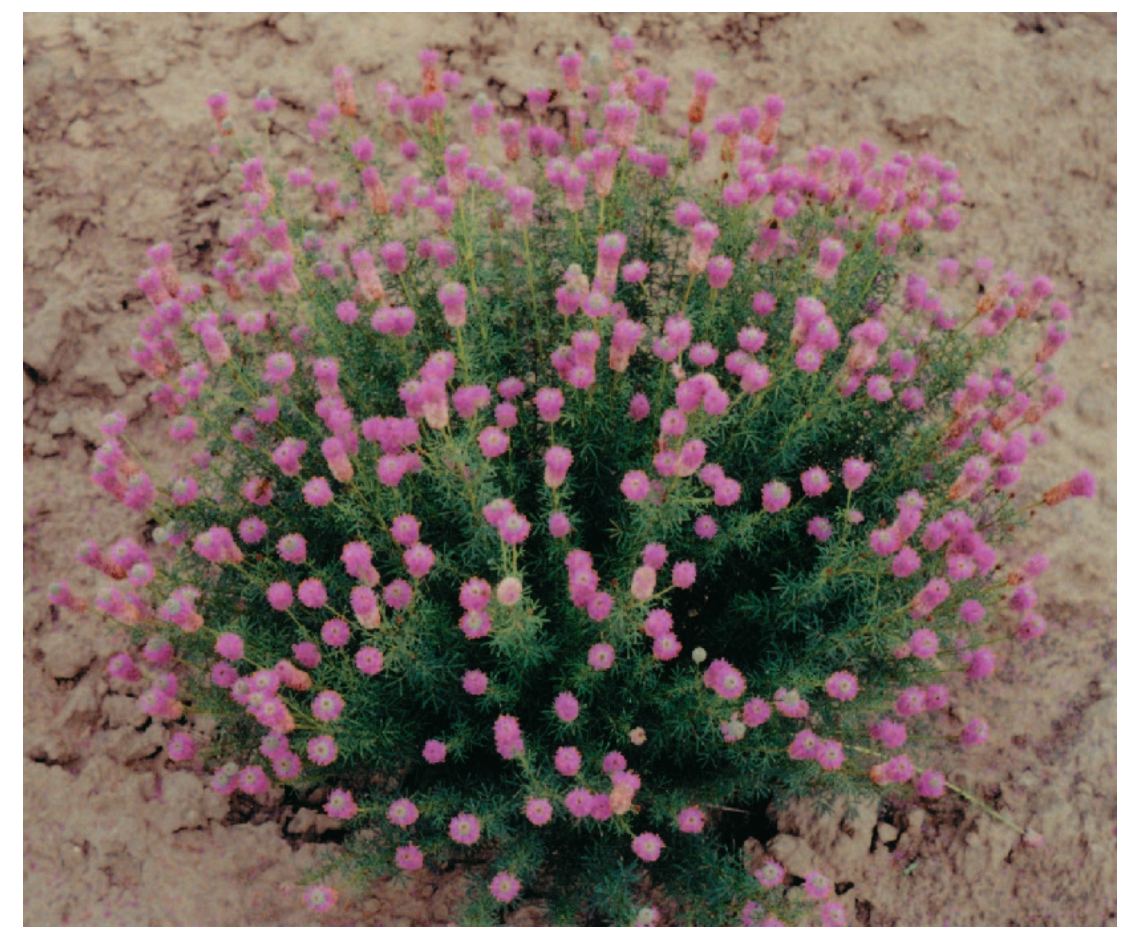




\section{Description}

A single population of $D$. purpurea in these trials was selected for release because of its attractiveness as a landscape ornamental plant. Its growth habit differs from plants of this species in native stands by its more compact nature or habit and its higher number of flower stems. It averages $45.9 \mathrm{~cm}(\mathrm{SD}=6.8)$ in height and 49.3 spikes $(\mathrm{SD}=21.7)$ per plant. Each spike terminates with one or more bright, lavender-colored flowers. When there are multiple flowers per spike, there is one central primary flower that is larger than the other flowers on the stem. The primary flower of each spike averaged $29.2 \mathrm{~mm}$ $(\mathrm{SD}=7.3)$ in length, and the secondary flowers on each spike averaged $12.3 \mathrm{~mm}(\mathrm{SD}=4.8)$ in length in 2001. It flowers from mid-July to the first week of August. Leaves average $22.6 \mathrm{~mm}$ (SD = 4.6) in length (Fig. 1).

In 1997 , the average percentage seed emergence for the 0 -week stratification treatment was $12 \%$ and for the 6 -week treatment was $51 \%$. In 1998 , the average percentage of seed emergence for the 0 -week stratification treatment was $16 \%$ and for the 6-week treatment was $29 \%$. There was a highly significant $(P<0.01)$ effect of treatment (weeks) on emergence over the 2 years. There was a nonsignificant effect due to years and a significant $(P<0.05)$ interaction between years and treatment (weeks). A mean comparison test (Fisher's LSD procedure) indicated there was a significant $(P<0.05)$ difference in emergence in 1997 but not in 1998 for the 0-vs. 6-week treatment. The interaction effect was due to the lower emergence for the 6-week treatment in 1998, which could have been caused by the seed medium drying out more during that treatment.
In 2001, individual flower heads were removed from 18 plants, and seeds per head were counted. The length of all heads varied from 7 to $44.5 \mathrm{~mm}(x=18.8, \mathrm{sD}=17.8)$, the number of florets per head varied from to 50 to $328(x=147.1, \mathrm{SD}=42.5)$, the ${ }^{-}$number of seeds per head varied from 31 to $80(x=70.3$, $\mathrm{SD}=42.5)$, and the percentage of florets with seeds ranged from $31 \%$ to $80 \%$ ( $x=49.9 \%$, $\mathrm{SD}=14.5 \%)$. Significant positive correlations were noted between head length and number of florets per head $(r=0.98)$, between head length and number of seeds per head $(r=0.83)$, and between number of florets per head and number of seeds per head $(r=0.81)$. The percentage of florets in individual heads with seed was not significantly correlated with any trait. The seed of this selection averaged 858 seeds per gram $(\mathrm{SD}=35.0)$ in 2000 .

No foliar diseases were observed on these plants, but crown and root rot was occasionally observed in the field. The plants are very attractive to bees at flowering. In 2000, about $10 \%$ of 'Stephanie' seed collected in the field was infested with the clover seed chalcid, Bruchophagus givvus (Boheman) (Metcalf and Flint, 1951). Seed infestation by the clover seed chalcid has been reported in alfalfa and several related species (Metcalf and Flint, 1951). In 2001, less than $1 \%$ of the $D$. purpurea seed was infested with this insect.

This selection is being released because of its shorter height, darker green foliage, and increased number of inflorescences compared to current selections and available germplasm. It is being released in conjunction with the Nebraska Statewide Arboretum as a Great Plants selection, in recognition of the centen- nial of the Univ. of Nebraska West Central Research and Extension Center and to honor the renovation of the gardens of the Nebraska governor's mansion, under the direction of Stephanie Johanns.

\section{Availability}

Correspondence concerning this release should be addressed to Dale T. Lindgren, Univ. of Nebraska, West Central Research and Extension Center, 461 West University Dr., North Platte, NE 69101-7756.

\section{Literature Cited}

Barneby, R.C. 1977. Daleae imagines. Memoirs New York Bot. Garden 27:892.

Farrar, J. 1990. Field guide to wildflowers of Nebraska and the Great Plains. Nebraska Game and Parks Commission, Lincoln.

Great Plains Flora Association. 1986. Flora of the Great Plains, p. 439-445. Univ. Press Kansas. Lawrence.

Lindgren, D.T. 1992. Variation in ornamental traits of Dalea purpurea Vent. (purple prairie clover). HortScience 27:927.

Locklear, J. and L.G. Vickerman. 1997. Dalea wakeup call. Amer. Gardener 76(4):28-33.

Metcalf, C.L. and W.P. Flint. 1951. Destructive and useful insects, p. 568. McGraw-Hill, New York.

Salac, S.S., P.N. Jensen, J.A. Dickerson, and R.W. Gray. 1978. Wildflowers for Nebraska landscapes, p. 1-27. Univ. Nebr. Inst. Agr. Nat. Res., Misc. Publ. No. 35.

Starr, G. 1988. Dalea, a genus of horticulturallypromising legumes for desert landscapes. Desert Plants 9:3-31.

Stubbendieck, J., J.T. Nichols, and C.H. Butterfield. 1989. Nebraska range and pasture forbs and shrubs, p. 57-58. Univ. Nebr. Coop. Ext. E.C. 89-118. Lincoln. 